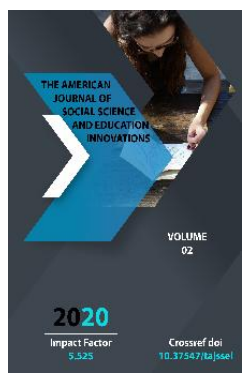

\title{
Combination Of European Music Culture With Uzbek National Art And Culture
}

\author{
Shuhrat Tolipovich Almatov \\ Lecturer, Faculty Of Folk Art, Department Of National Singing Art, Uzbekistan State Institute \\ Of Arts And Culture, Tashkent, Uzbekistan
}

Journal Website:

http://usajournalshub.c

om/index,php/tajssei

Copyright: Original

content from this work

may be used under the

terms of the creative

commons attributes

4.0 licence.

\section{ABSTRACT}

This article discusses the comprehensive impact of European music culture on the Uzbek national art and culture, as well as how to combine the heritage of the spiritual treasures of our people, which is widely developed in harmony with human development. It contains the necessary ideas and reflections on the vast sources of creativity and the role and influence of European music culture, which have been diligently studied by each generation and call for a worthy successor to our art and culture for the future. In the article you will get an idea of the trends in music creation of all European countries, which are classics, and their integration with our art and culture.

\section{KEYWORDS}

Music, classical, European, Uzbek, art, culture, history, past, future, national, traditional, source.

\section{INTRODUCTION}

The musical culture of the Uzbek people has a very long history. Throughout historical development, folk classical music, traditional professional music, folk compositions, as well as folklore - amateur musical heritage have complemented each other in forms and styles of close performance. The process of harmonizing European music with our national and spiritual values, traditions, art 
and culture, the process of their new reform has become a priority in the manifestation of this musical heritage as a part of our spiritual culture today. It is no exaggeration to say that the influx of European music has had a positive impact on our national values, traditions, art and culture. From the first years of independence, work is being done to carefully preserve and restore the spiritual riches and musical culture inherited from our ancestors. At the same time, a lot of work has been done to reveal the harmonization of the aspects of Europe that have surpassed us in keeping pace with the times. In this regard, the great spiritual wealth inherited from our ancestors serves as a key factor.

\section{THE MAIN RESULTS AND FINDINGS}

It is known from history that our musical culture, art, traditional songs, maqom performances, which are the main link of our spirituality, have always been recognized as spiritual food in the daily life of our people. The people sought salvation from music in their difficult days, and songs and music accompanied them in their days of joy. After all, today, on the day of our blessed Independence, at a time when we are realizing our identity, it is natural to rely on our national musical culture, which is part of our great spirituality, inherited from our ancestors, to address our traditional songs. All this plays an important role in the upbringing of a harmoniously developed generation, in the formation of the spiritual worldview of young people.

It is no secret that our traditional music and songs have brought European music into our art and culture with unique style directions. Even today, without losing its relevance, European tones will remain a key factor in shaping our art and culture, introducing the harmoniously developed generation to world culture and art. The art of singing, music, dance, folklore performance is one of the ancient arts that emerged and developed in close connection with the life and work of the people of national music. In particular, the traditional songs of our people are an immortal legacy, and today, as in all times, it is answered as "of course"("labbay"). But at the same time, the era itself demands that our art and culture be harmonized with European music, not only in the worship of history, but in the creation of songs in accordance with the spirit of today. Our country has started a completely new society, a new life and a new life. There have been changes in the hearts, minds and imaginations of our people.

As the President Sh.M.Mirziyoyev noted, the issue of spirituality includes many factors such as the history of the nation, moral and religious values, cultural heritage, traditions and customs, national ideology, patriotism and humanism, understanding of national identity and, ultimately, the definition of human identity. serves as the main criterion. "The future of our people depends, first of all, on itself, its spiritual power and the creative power of the national consciousness. The natural pursuit of material well-being should not impede the nation's need for spiritual and intellectual growth. Spirituality and enlightenment have always been the strongest feature of our people for many centuries, "the President said. These ideas, which are highly acknowledged by him, amaze the people of Europe and the world, and arouse the interest of the world in our art and culture. Based on these principles, all directions of European music will need to define their goals and objectives and put them in place and use them when needed. Especially on this front, it is important to appreciate the unique place of musical culture 
in life, to understand that its main criterion is to direct the power of its impact on our national art. There are shifts in culture and art today according to this principle. It would not be a mistake to say that the minds of the creators are guided by these principles.

European music is distinguished by its versatility. Especially today, with its deep roots, combined with the rich musical heritage, art and culture of the Uzbek people, which goes back to ancient times, it shows a special charm. It includes high samples of folk art, folklore performance, melody structure, content-rich instruments and songs, performance of epics, and a series of complex performances called "maqom" music. In addition, the works of folk composers, who have made a significant contribution to the harmonization of European music with our national culture and art, also play an important role.

At the end of the XIX century began a period of change in Uzbek musical culture. This, of course, is due to the Russian occupation of Turkestan. It will be necessary to study this with a two-pronged approach. Because in some cases, if we observe the negative impact of national music on our culture, on the other hand, it is necessary to recognize that it was a period of specific development. Because the introduction of the notation in European music has had a significant impact on the scientific study of the art of national music in our country, the development of folklore and ethnography. In this regard, it is necessary to mention the work of musicologists and ethnographers such as V.A.Uspensky, E.E.Romanovskaya, N.N.Mironov. Our musicians such as llyas Akbarov, Mutal Burhanov, Yunus Rajabiy, Tolibjon Sodikov, Mukhtor Ashrafi learned from them. In addition, the introduction of piano, opera and ballet, symphonic performance, world classical music, which are considered the masterpieces of European musical culture, has made a significant contribution to the multifaceted development of our musical culture. As a result, more than 20 volumes of books containing Uzbek folk music, songs and "maqom"s have appeared around the world.

For the last 130 years, our musical culture has gone through a historical period full of complex, sharp contradictions, positive and negative views. Despite these circumstances, it is necessary to recognize that in the past, a lot of work has been done in the field of science, art, including music culture. Examples include music creation, performance, music science, and analysis. The negative consequences of these past periods include over-politicization of our lives, disregard for our national values, their suppression, indifference to popular tendencies, artificial barriers to the development of ancient international cultural relations. Let's take a look at the history of pop and choral music, which plays an important role in European music culture. Reminiscent of the shape of a horse's bridle, the ancient Greek theaters were able to accommodate 20,000 to 25,000 spectators. They equipped the place, which was flat in the middle and surrounded by a hill, and called it a stadium. While one side of the hill town, which is surrounded on three sides by earth, consists of a plain, the place was called a furnished-theater. So the Greeks called the place where the audience sat the theater. The closest part of the plain to the spectator, the front part, was called the orchestra, the place where the choir was located. Even today, in musical theaters, an orchestra and a choir are placed between the audience and the stage. To ensure a better view of the audience, Coryphaeus, who interacts with the choir and directs it, was placed on a specially equipped - wooden bed at the back of the orchestra. Because the 
prestige of the choir was so high that it was impossible to walk in front of it. Later, the first actor also came out on the couch to communicate with the luminary and the choir. The appearance of the first actor on the stage with Coryphaeus required a further expansion of the wooden equipment, and the Greeks called it "variety", ie the stage, literally" a special place of ascent". This means that it is a specially equipped place for the performance of pop actors, and the term stage still retains its essence. The ancient Greeks called the skene a special tent behind the stage. There, the actors struggled and kept the stage equipment. Thus the direction of variety and choir originated in Europe.

The harmonization of European music with Uzbek art and culture is seen as a dynamic process in the development of modern Uzbek music, which is multifaceted, rich in style and colorful. Indeed, our musical culture has a very ancient, unique and unique tradition, and with the passage of time it is becoming richer and richer with new European musical trends, forms, genres and styles. This means that along with our glorious heritage, which has come down to us over the centuries, the beautiful musical traditions of several generations of artists have become our cultural and spiritual property. While any art form is able to reflect the realities of life through various means, it is clear how complex and changing social conditions the development of Uzbek music has taken place over the past hundred years. In particular, the arrival of composers from Europe in the $1920 \mathrm{~s}$ in our country testified to the establishment of a new system of musical creativity in our musical culture.

Naturally, Uzbek folk art, traditional composition and amateurism will soon be closely intertwined with European music, and "non-traditional" compositional creativity will join our national values as an important sector. In accordance with the universal cultural development, it should be noted that this direction has been formed and developed in a very short period of time in our country.

In order to not only make effective use of the experience of Western and Eastern European countries, but also to master the rules of unique creativity, skillfully infuse it with the rich potential of Uzbek folk music, our leading composers have achieved great success not only in Europe but also in the world. Given its development in the creation of a unique modern work in a new musical style, taking into account the development of European folk music, Uzbekistan has been able to confidently enter the international process, which is characterized by the opening of new creative horizons. Having rapidly passed the stages of professional development and reached the stage of comprehensive maturity, the "Uzbek School of Composing" has sought to take its rightful place in world music culture.

The level of inclination to such creativity, which emerged mainly in the second half of the twentieth century, is also characterized by the fact that in our country there is an integral commonality of the traditions of two categories of musical thinking, which were previously separate. For this reason, artistically harmonious, classical works of various genres, created in a multi-voiced style, have further enhanced the global potential of our art and culture.

Let us recall that as a result of the harmonization of European music with our Uzbek national art and culture, Uzbek symphonic music, which is a new direction, took the lead in the 705 and 80s. Suffice it to 
say that it has been successfully performed at prestigious cultural events, concerts, competitions and festivals in our country, neighboring and a number of European countries. Uzbek poems, suites, overtures, fantasies, instrumental concerts and symphonies have repeatedly attracted the attention of the international music community.

Today, the art of Uzbek music is increasingly recognized internationally, not only in its original traditional forms, but also in the European direction of music composition. In this sense, pure instrumental music, especially his more complex symphonic works, deserves special attention. Nowadays, the composition of the republic is not only a series of experiments in writing and research in various musical genres, but also a fruitful movement with a unique tradition, a treasure trove of classical samples. It consists of unique and inimitable works created on the basis of folk melodies in different years. After all, the qualities of music composed in any style, such as nationalism, modernity, artistic perfection, originality, content, impact, are always valuable.

The longevity of the works created on the basis of ancient national traditions with high professionalism, deep knowledge and delicate taste can be clearly seen only in the example of Uzbek symphonic music. In particular, the passionate poem "Tanovar" and suite "Lola", adapted to the voice and symphony orchestra of Alexei Kozlovsky, created in the second half of the 30 s of the XX century as a result of combining European music with Uzbek national art and culture, Reyngold Glier's "Fergana holiday" has been giving pleasure. Among the works of immortal discovery to be performed with the participation of the symphony orchestra are Mutal Burhanov's
"Poem for Alisher Navoi" for solo, choir and symphony orchestra, a number of symphonic works by Mukhtor Ashrafi, Georgiy Mushel, Sulaymon Yudakov, Doni Zokirov's "Lyric Poem", Boris Nadejdin's suite "To the children", Ikrom Akbarov's "In memory of the poet" and "Epic poems", "Samarkand stories" series, Sayfi Jalil's "Samarkandnoma” symphony, Tolkin Kurbanov's symphonic melodies, Mirsodiq Tadjiev's poem "Poet's love" and his 19 great symphonies, Mirhalil Mahmudov's of 3 symphonies, Nurilla Zokirov, Mustafo Bafoev, Rustam Abdullaev, Habibullo Rakhimov, Bakhrullo Lutfullayev and other artists have made a worthy contribution to the development of our musical culture.

The development of the art of music in our land dates back to three thousand years. During these difficult times, our musical culture has many times gone through its own long period of development and has served for goodness and progress as the basis of the spiritual wealth of our people. That is why we have a very rich, colorful, wide-ranging, stylistic diversity, a truly invaluable musical heritage of invaluable level. In the Middle Ages, only in the classics of classical art was there such a magnificent system as "Twelve maqoms", on the basis of which were formed Bukhara and Khorezm maqoms, FerganaTashkent maqoms, traditional performance and trumpet ways, composition, composition and variety of Uzbek music. It is no exaggeration to say that the harmonization of national art with culture has made a significant contribution to its further development.

\section{CONCLUSION}

In short, the role of key factors in the harmonization of European music with the Uzbek national art and culture has played an 
important role. In particular, the study of the history of the introduction of European music, the stages of development of our national art, culture and the scientific significance of its study, the role and importance of foreign experience in the development of our art, the role and importance of Uzbek national culture, the harmony of European and European tones. Issues such as the study of the importance of the musical creativity of the representatives of the arts and culture of our country were described step by step. If we can make a deeper and more effective use of the positive aspects of the issues we have raised above, it will certainly be able to raise the global position of Uzbek national art and culture to a higher level.

\section{REFERENCES}

1. Speech of the President of the Republic of Uzbekistan Sh.M.Mirziyoev at the meeting with culture and art activists on August 7, 2017. People's Word newspaper August 8 issue.

2. Bekmatov S. (2007). The art of memorization. Educational-methodical manual. P.135.

3. Rajabov I. (1992) Basics of status. Tashkent. Pages 10 - 15.

4. Michael Pilhofer (2007) Holly Day. Music Theory for Dummies. Pp.10-12.

5. www. pedagog .uz

6. www. google. uz

7. www. mail. uz

8. www. tdpu. uz

9. www. ziyonet. uz

10. www. edu. uz 